\title{
Adaptive reuse to concept of land use planning and design. Case study: Independent integrated city in Morowali, Central Sulawesi
}

\author{
Irdinal Arief ${ }^{1^{*}}$, Harifuddin Thahir $^{2}$ \\ ${ }^{1}$ Department of Architecture and Planning, Faculty of Engineering, State University of Tadulako, \\ Mantikulore, Palu, Central Sulawesi, 94148. Indonesia \\ ${ }^{2}$ Department of Management, Faculty of Economics, State University of Tadulako, Mantikulore, Palu, \\ Central Sulawesi, 94148. Indonesia
}

\begin{abstract}
Re-adaptation is a method of controlling the use of space, it is also related to and applies to regional regulations regarding the spatial plan of Morowali Regency which is determined as an independent integrated City area in Bungku. The trend of land use at the independent integrated city, Bungku Central Zone, until now functionally has experienced many developments. The main function of the region since its inception was developed as a Regional Government Centre. Sustainability as an important concept in the 20th century has defined "meeting the needs of the present without compromising the needs of future generations" by the World Commission on Environment and Development. In architecture sustainability is characterized as a system which investigates the relationships between the built environment and human being, economical usage of sources and reuse activities, contributes to form liveable environments, improve life quality and provide continuity. Adaptive reuse is one of the sustainable architecture components is seen as an issue to be handled as sustainable resource usage. The sustainability understanding which has a goal considering the balance of economic growth with conservation - aims to prevent the destruction and disappearance of cultural assets and improve by conserving.
\end{abstract}

\section{Background}

Central Bungku Subdistrict is one of 9 Subdistricts in Morowali District after experiencing expansion from North Morowali District in 2014. Since its inception, this district has been designated as the Capital of Morowali Regency which is strategically located because it can be reached by land and sea from district area around it.

\footnotetext{
${ }^{*}$ Corresponding author: irdinalarief@gmail.com
} 
Land use in Central Bungku District is dominated by forest, reaching $83 \%$ of the total land area or 63,010,468 ha. While the smallest land use is sea sand with an area of 8.172 ha. For more details about land use in Bungku Tengah District can be seen in the following land use tables and maps. (See Figure 2). From the data, spatial and regional plans Morowali in 2012-2023, divided the land area as follows: Mangrove 67,515 ha, Forest 52,417,405 ha, Plantation 1,306,922 ha, Sea sand 8,172 ha, Settlements 650,286 ha, Shrubs 264,295 ha, river / lake 195,149 ha, and moors 8,100,725 ha.

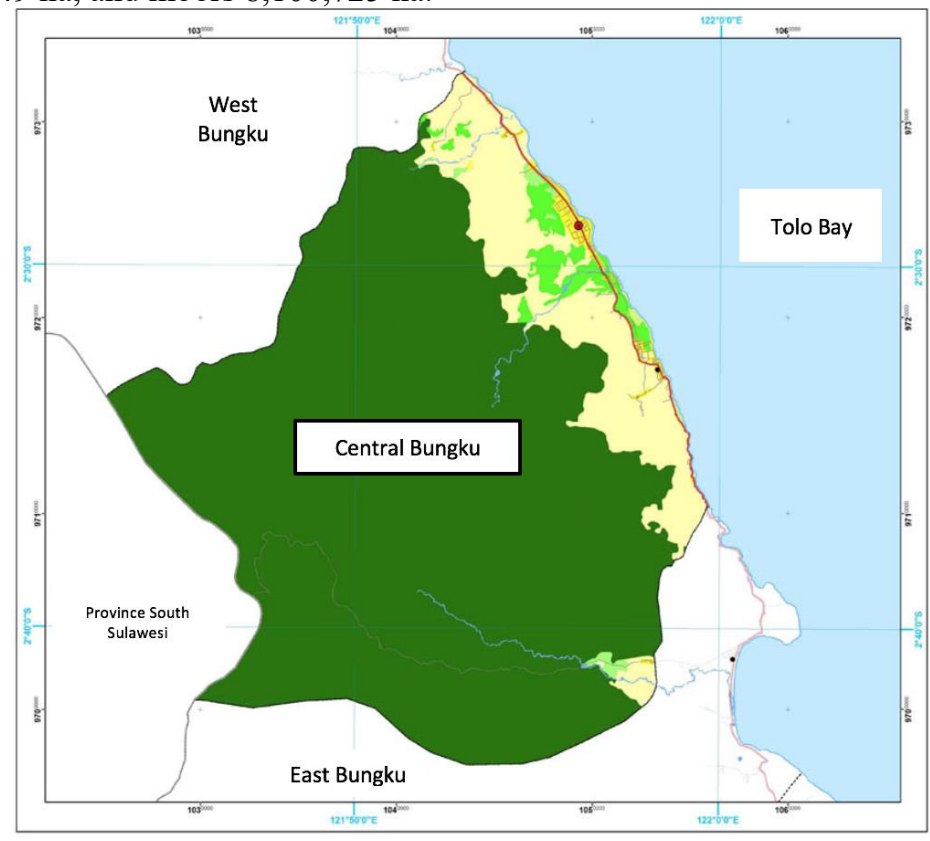

Fig. 1. Map. Land use in Central Bungku District, Morowali

From the data, spatial and regional plans Morowali in 2012-2023, divided the land area as follows: Mangrove 67,515 ha, Forest 52,417,405 ha, Plantation 1,306,922 ha, Sea sand 8,172 ha, Settlements 650,286 ha, Shrubs 264,295 ha, river / lake 195,149 ha, and moors $8,100,725$ ha.

The Integrated City Centre Area is a strategic location. It is supported by the existence of the East Cross Trans Sulawesi road network which is connected directly to the main access or the gateway to the place, resulting in a fairly busy flow of transportation. In addition, within the design area itself is already equipped with a road network that most have not experienced pavement.

The electricity network is intended for lighting the place. One energy source that is absolutely fulfilled is electrical energy. The fulfilment of electricity needs in a city is expected to be able to support the activities of the population and ultimately will improve the economy of the community. In line with the development of it's with the intensity of the current socio-economic activities, the electricity network services have reached several points in the place Area through a distribution network system. Whereas the fulfilment of the need for clean water at the Integrated City Centre is served by using a piping system that is channelled throughout the region. 


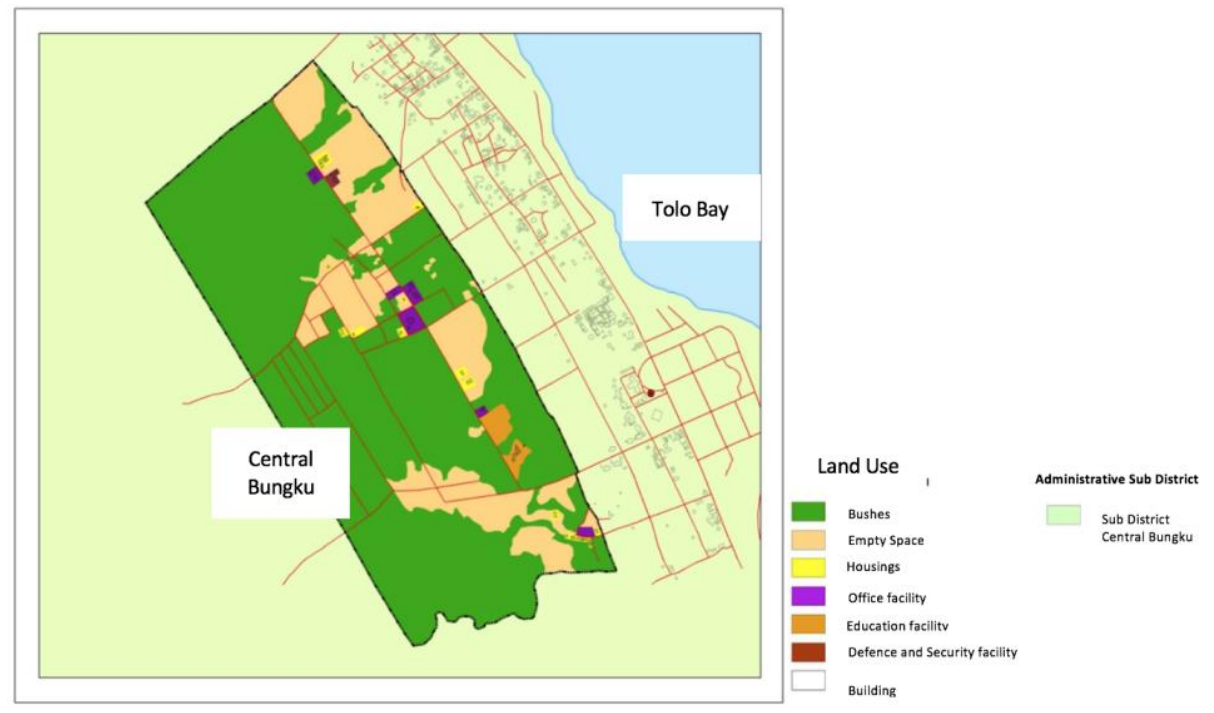

Fig. 2. Map of Initial land use conditions

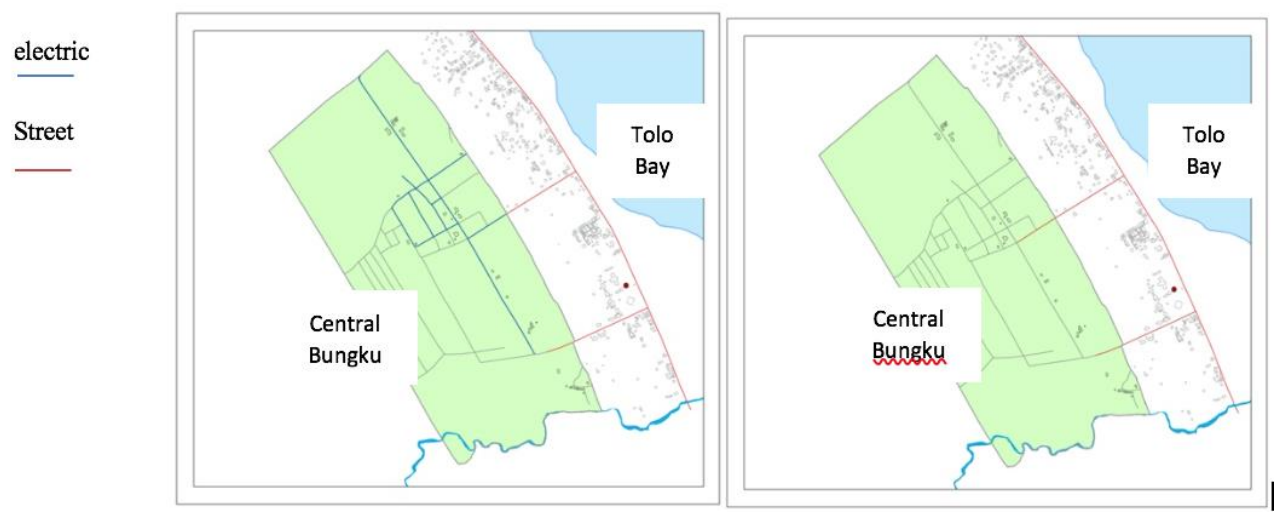

Fig. 3. Map of electric network and street, The Bungku, Independent integrated city

\section{Purposes of research}

The purpose of this study, is to re-adapt land use and control of spatial use, which is aligned with local regulations on spatial planning in Morowali Regency. Adaptive land use reuse that can have a major role in sustainable development. When adaptive reuse involves historic buildings, the environmental benefits are more significant, because they offer so much to the landscape, identity, and convenience of the communities in which they are located.

One of the main environmental benefits of reusing land use and buildings is the retention of "energy contained". By reusing, energy can be maintained, making it far more environmentally friendly. In this case reuse and restructuring, appropriate land use and land potential, so that the synergy between sustainable land use and spatial hierarchy, seen from socio-cultural, economic, and environmental 


\section{Theory of Adaptive reuse to concept of land use planning and design}

Sustainability has five principles. There are; maintain, and where it has been disturbed, restore biodiversity; minimize the consumption of resources, especially non-renewable resources; minimize pollution of soil, air, and water; maximize the health, safety, and comfort of building[4]. The creation and responsible management of a healthy built environment based on resource efficient and ecological principles [4].

Adaptive reuse is described as "developing the potential of additional use and wear for a functionally obsolete building. It is basically the act or process of making possible a compatible use for a property through repair, alterations, and additions while preserving those portions or features which convey its historical, cultural, or architectural values. The concept is not constrained by what the building used to be, but respects the history and structure as a new program is inserted [6].

Adaptive reuse is a tool to rescue historical environments and the buildings located there from deconstruction. The formation of sustainable environment will be supported if this condition is provided. However, adaptive reuse studies are very important for environmental sustainability and energy efficiency although its cost is high [7].

Adaptive reuse of buildings is preferred with its advantages such as being economical, providing cultural and historical continuity, keeping a process of effort rather than energy alive, increasing environmental energy consumption and at the same time being an indicator of ecological approaches. When the adaptation of reuse is successful it will be possible for the building to continue its life with its new function mention the life quality as the new users of the building will be satisfied in the spaces they experienced and fulfil an urban requirement with the new function [1]. So, economical, socio-cultural and environmental benefits and sustainability will be provided by giving the appropriate function to the building. At the same time the value of the buildings will increase as long as they are used.

At the point where the social, cultural, economic and environmental sustainability of the building's new function is provided, it is a fact that the physical life of the building will be ensured [8]. At this point the adaptive reuse of monumental buildings is handled in the scope of economical, socio-cultural and environmental sustainability.

Third basic things in the arrangement of Adaptive reuse is:

Socio-Cultural Sustainability: Cultural continuity can be defined as the change of the community without losing its identity and origin by adapting to the requirements of the era. In architecture cultural continuity is the duty and the responsibility of each generation to get the cultural values and indicators from the previous period, interact with other cultures, add them new ones and transfer them to next generations [8].

Economical Sustainability: A sustainable economic development is depended on the natural resources which are conserved and used. The historical environments and the buildings located there as a part our cultural heritage, play an important role in both providing economical and socio-cultural sustainability as long as they are conserved and used [8].

Environmental (Ecological) Sustainability: Environmental sustainability 8means providing the continuity of natural resources. Against the rapid consumption of energy and renewable materials in global scale, the formation of a new approach in resource usage is basic component of sustainability. This means reuse or recycle of waste materials and abatement of total material consumption.

Components of Reuse and realignment, refer to the table to be displayed, Socio-cultural, economic and environmental sustainability components of adaptive reuse can be seen in Table 1. 
Table 1. Socio-cultural, economics and environmental sustainability components of adaptive reuse

\begin{tabular}{|c|c|}
\hline \multicolumn{2}{|r|}{ Sustainability components of adaptive reuse } \\
\hline Socio-Cultural & $\begin{array}{c}\text { Original function of the building should be known } \\
\text { New function of the building should be known } \\
\text { The building becomes reference point by new function } \\
\text { Perception of the building's symbolic value } \\
\text { Expression of the building's architectural history and art value } \\
\text { Conservation of the building's cultural values } \\
\text { Conservation of the building's originality values } \\
\text { fabric, colour) } \\
\text { Conservation of the building's document values } \\
\text { Including the building in the living area again } \\
\text { Conservation of the building's aesthetical value (proportion, scale, form, material, } \\
\text { Contribution to city publicity } \\
\text { Contribution to city identity } \\
\text { Increase the building's life quality } \\
\text { New function should agree with the social and cultural structure of the city } \\
\text { Conservation of the building's socio-cultural value (economical, functional, } \\
\text { Social, cultural and economic benefits for its users } \\
\text { New function support user activities and social life } \\
\text { New function fulfils social needs } \\
\text { Visual contribution with its new function to the environment } \\
\text { Being saved from the ruin appearance/preventing visual pollution }\end{array}$ \\
\hline Environment & $\begin{array}{l}\text { Visual completeness with the environment and contribution to the environment } \\
\text { The harmony between new function of the building and its environment } \\
\text { Its quality to attract attention with some symbolic characteristics in the fabric and } \\
\text { being a tool for description } \\
\text { Being saved from the ruin appearance/preventing visual pollution } \\
\text { Physical lifetime is extended by maintenance and repair in the usage process of the } \\
\text { building } \\
\text { Abatement of the harm done to the environment by the means of adaptive reuse } \\
\text { Less consumption of natural resources } \\
\text { Extend the life time of the old by repair } \\
\text { Abatement of waste material }\end{array}$ \\
\hline Economical & $\begin{array}{l}\text { Adaptive reuse is economical in the long run } \\
\text { Abatement of natural resources consumption and contribution to the economy } \\
\text { Extend the life time of the building } \\
\text { Give importance to historical and cultural values and gain benefits in tourism } \\
\text { sector }\end{array}$ \\
\hline
\end{tabular}

Bold Text: Components applied to plans and designs

\section{Method}

Data collection is carried out in this study using Adapters which are done by collecting data through primary and secondary surveys, media reviews and literature studies. In general, the methodology of adaptive reuse is part of a more sustainable pattern of development, which can utilize the general principles of sustainable design and adaptive reuse for rebuilding (Snyder, 2005). In this context too, the reuse of existing buildings is not destroyed. Adaptively existing as a building reserve is a subject that must be resolved as a supported resource. Using existing building reserves with new functions that are of general benefit providing Environmental Benefits each new building can damage the natural environment in 
the development process. Reuse in adaptation in optimal use of resources can be accepted as important in the agreed summary [1].

Analytical techniques that will be used to achieve the objectives and targets, among others, by using descriptive qualitative analysis method.

\section{Result of Independent integrated city in Morowali}

\subsection{Spatial planning refers to adaptive reuse}

The planned block distribution is the division of a plot of land that is limited by tangible physical constraints (such as road networks, rivers, sewers, irrigation channels, high voltage airways, beaches, etc.), as well as unreal and other similar infrastructure network plans according with the area's spatial plan.

The regional development plan through adaptive reuse, then the plan for an integrated urban area space structure is carried out by establishing hierarchical centres and related to the Morowali District service centre system. The spatial structure plan with the development of activity centres in integrated independent city areas, among others.

1. Main Regional Activity Centre (Socio-cultural)

The Regional Main Activity Centre is planned to be located in Block A, Block B, Block $\mathrm{C}$ and Block $\mathrm{D}$, with activities dominated by government offices, trade services that are integrated with private offices, and education at regional and district scales which are encouraged to become activities in and around independent integrated city area.

2. Economical Centre for Activity Support (Economical)

The Centre for Area Support Activities is planned to be located in Block D, Blok F and Block $G$ with activities consisting of local transmigration housing, industry and warehousing, defence and security, health and green open spaces.

3. Centre for Buffering Activities (Environmental)

The Regional Buffer Activity Centre is planned to be located in Block E, Block F and Block $G$ with a variety of activities consisting of agricultural and plantation activities, steep topography land conservation and river boundaries.

\subsection{Plan for regional spatial patterns}

Space allocation distribution plan in a planning area which includes the allotment of space for protected functions and cultivation functions which are further elaborated in each zone and subzone consisting of local protection zones, housing, trade and services, offices, industry, defence and security and the green open space which is then depicted in blocks in the area. The results of the spatial pattern plan are then contained in a map that also functions as a zoning map for zoning regulations. Block of District and Map of Zone, Map of Development City shown on Fig.4 and Fig 5.

The spatial pattern plan refers to the zoning block and the development of the activity centre, so that spatial patterns can be created based on ground $g$ theories understood from urban planning as a textual relationship between the built form (Building's) and Open Space. Figure / Ground Analysis is an excellent tool for identifying a texture and patterns of an urban spatial.

Plans for spatial patterns include planning that is considered from, human resources, maintaining the natural environment, utilizing energy from natural resources, or making technology from renewable energy. 


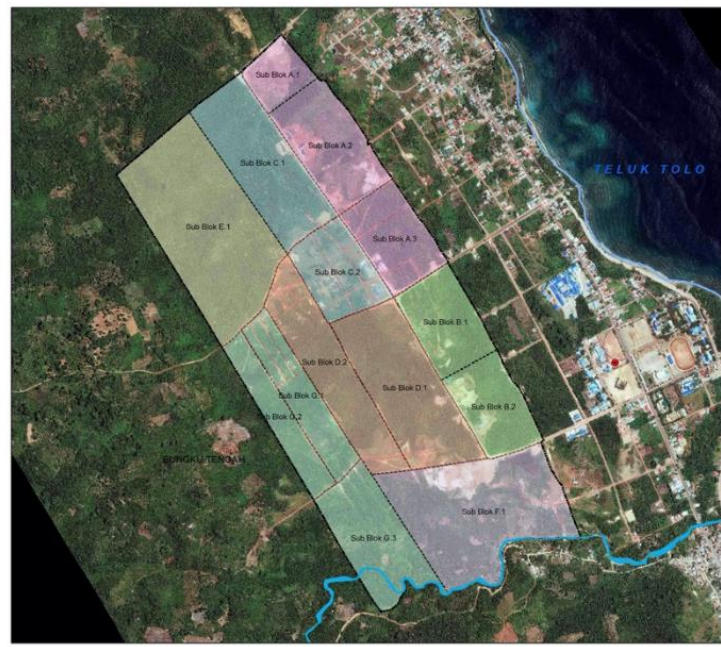

Part of Block

Block A

Block B

Block C

Block D

Block E

Block F

Block G

Fig. 4. Block of District

Consideration of planned spatial patterns of natural resources around the site, including many sago forests, plantations, rivers and seas. So, it needs a very green path and forest conservation area, especially sago forest, which is one of the potentials that can be cultivated to increase the economic value of the community. However, the sago forests in the integrated city area are no longer used by the community to increase income so that the existing sago forests can no longer have significant economic value for the community. However, given the history of sago forest which has a very important role for the community to survive and improve the economy of the community in the past, the sago forests that lie on several spots in the Central Area are integrated city areas planned to be protected by establishing sago forests that there is a green open space whose function can be used as an icon / landmark of the area through sago forest arrangement. The map Development activity center shown on Figure 5 .

The next consideration is human resources, the large number of migrants from outside the area bordering on the location of an integrated city area. Space requirements for transmigration need to be considered as the main container in activity activities, besides being designated as the centre of government and CBD (central business district).

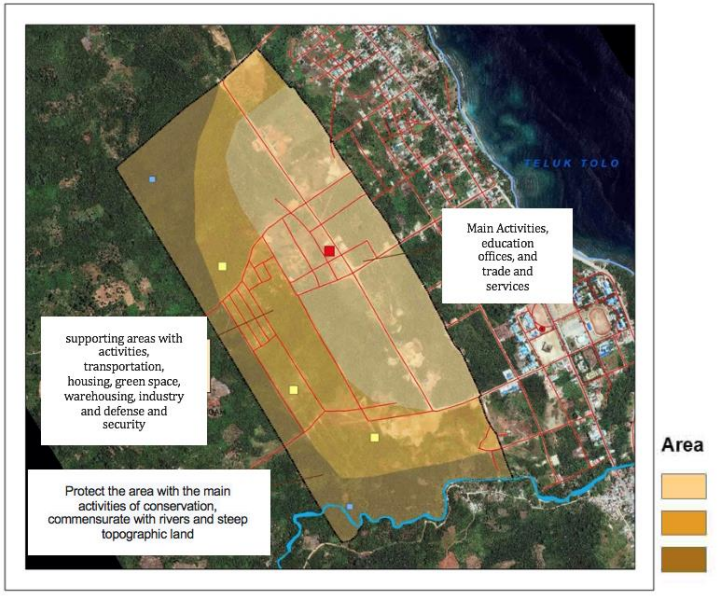

Central of Service District

Central of Sub Service District Buffer Zone

Fig. 5. Map of Development activity center 


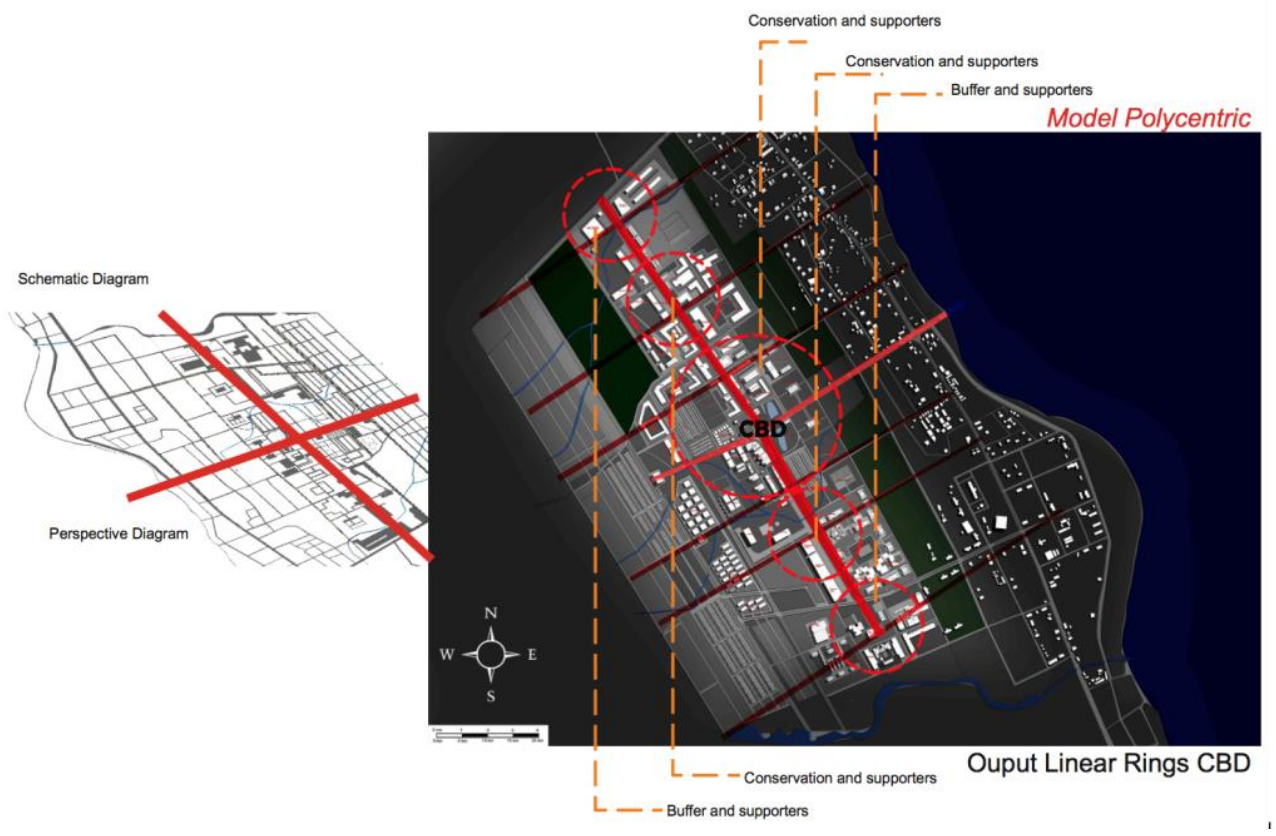

Fig. 6. Map of Model Linear Pattern, Polycentric

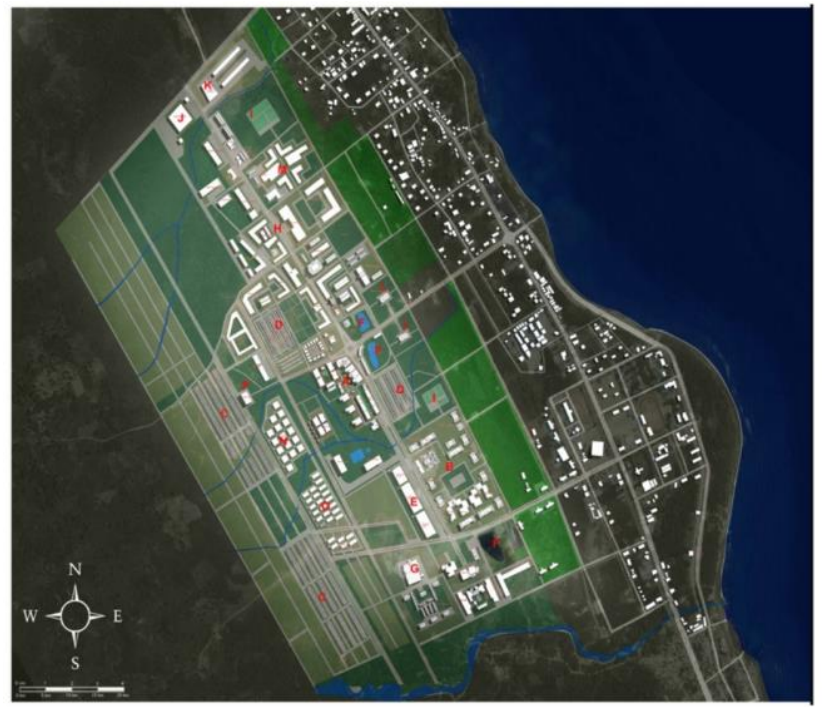

Fig. 7. Map of Planning and design, Independent integrated city in Morowali

A built environment cannot be felt in the absence of an underlying cognitive chart. In this case the forms and patterns that already exist have several influences as the direction (old patterns and or new patterns) must exist so that a form can be raised. These forms always describe a match between the organization of physical space and the organization of social space. Besides this pattern is based on consideration of several aspects that have been analysed previously 


\section{Implementation}

By paying attention to the conditions of the planning area that continues to grow with the dominance of government office activities whose implementation of space utilization is not in accordance with the direction of the previous plan so as to reduce the development of other activities such as service trade, industry and green open spaces which have implications for the loss of development orientation of the supporting activities of the Region. For this reason, a space pattern plan is needed to direct and control the use of space.

As for the plan to develop space patterns in adaptive reuse to the concept of land use planning and design, the autonomous city area consists of:

- River border zones by limiting the growth and development of aquaculture activities through setting the border distance of the river according to the criteria set.

- Green open space zones, city parks and urban Forests

- Housing zones, which can be broken down into housing developer sub-zones as well as the transmigration local housing sub-zone

- Trade and service zone, which includes daily markets and shops

- Office zones, which include government and private offices;

- Industrial zones, which include various industries and small industries;

- Agriculture and plantation zones;

- Education zone;

- Health zone;

- Transportation zone; and defence and security zones

- Renewable energy zones, in the form of retention ponds or artificial lakes, and solar panels on street lights and public buildings

In general, the plan to develop the regional infrastructure network is carried out with a plan to develop an integrated infrastructure network to support efforts to develop the planning area and be integrated with the road network. This is intended to be easy to maintain, control and not interfere with the appearance of buildings and the environment. Infrastructure network services also involve the service system and capacity that must be provided.

Improving the quality of governance in the concept of reuse, made in the zone scheme is a consideration in the design of an integrated city in Bungku, Morowali. which results in sustainable designs, such as, environmental sustainability that provides sustainable natural resources, for fast energy consumption and renewable materials on a global scale.

\section{Conclusions}

The contribution of adaptive reuse - as a sub-activity of conservation concept - to sustainability is related not only to the building itself but also the quality of the fabric it is located in. adaptive reuse is a tool for sustainable conservation, and it finds itself a place in the conservation understanding. It is important to handle a culture asset in a historical environment or any urban fabric with its environment from the point of the contribution to sustainability. In the context of adaptive reuse, the positive values of sustainability components are related to the qualities of physical environment. The qualities, functions of the buildings in physical environment and its relationship with the culture asset are effective on determination of the conservation understanding quality. That quality becomes an important input for determining and selecting the function which will be given to culture asset, continuity of usage and positive evaluation of sustainability components. Referring to the direction of independent integrated city development on the development of natural resources, human resources, and (artificial resources which include infrastructure and development facilities) so that development is able to bring progress, prosperity and 
independence in a fair and sustainable manner. Allocation of utilization of land (spatial) control for protected areas (preservation and conservation) and cultivation areas (development). And the direction of the composition and level of various development activities that are efficient, fair and environmentally friendly.

\section{Acknowledgements}

This study is supported by Development Planning Agency and regional research, labor and transmigration services, Morowali, Central Sulawesi.

\section{References}

1. Aydın, D. Socio-Cultural Sustainability and An Assessing Model for Reuse Adaptation, Central Europe towards Sustainable Building from Theory to Practice, International Conference, CESB10, Prague. 531-534. (2010)

2. Aydin, D., Yaldız, E., \& Siramkaya, S. B. Evaluation of Domestic Architecture Via the Context of Sustainability: Cases from Konya City Center. International Journal of Architectural Research: ArchNet-IJAR. 305-317. (2015)

3. BAPPEDA. Spatial Planning and Territory 2015-2035, Morowali (2015)

4. Cordero, E. Sustainability İn Architecture, Master of Science In Architecture Studies In Building Technology At The Massachusetts Institute of Technology. (2001)

5. Langston, $\mathrm{C}$. The sustainability implications of building adaptive reuse. http:// epublications.bond.edu.au/sustainable_development/4. (2008).

6. Snyder, H., G. Sustainability Through Adaptive Reuse the Conversion of Industrial Buildings. University of Cincinnati, in the Department of Architecture of the College of Design, Architecture, Art and Planning, Master thesis. (2005)

7. Wilkinson, S., J., Reed, R., G., "The Business Case for Incorporating Sustainability in Office Buildings: The Adaptive Reuse of Existing Building”, 14th Annual Pacific Rim Real Estate Conference, Kuala Lumpur, Malaysia.

8. Yaldız, E. Reuse of Monumental Buildings as A Sustainability Component, Central Europe Towards Sustainable Building. Conference, CESB10, Prague; 643-648. [http://www. irbnet.de/daten/ iconda/CIB17903.pdf ]. (2010) 